\title{
A Research on the Influential Factors to Organizational Commitment in IT Industry
}

\author{
Xing-Yuan HUANG ${ }^{1,2}$, Qian WANG ${ }^{3}$ \\ ${ }^{1}$ Dalian University Of Technology, Dr., Dalian, Liaoning, China \\ ${ }^{2}$ Dalian Polytechnic University, Dalian, Liaoning, China \\ ${ }^{3}$ Dalian University Of Technology, Doctoral tutor, Dalian, Liaoning, China
}

Keywords: Organizational commitment, The influence factors to organizational commitment, Human resources management.

\begin{abstract}
How to deal with the relationship between the organization and employees is the core of Human Resource Management in today's society. In recent years employee dismission rate in IT industry in China is very high, one of the causes of which is their low organizational commitment. Therefore, it is of great strategic and practical significance to promote employees' organizational commitment in IT industry. Human resource practice has an obvious influence on organizational commitment and the latter in turn predicts business performance. Thus, this research will benefit IT enterprises by finding out the reason for employee's turnover and putting forward appropriate countermeasures.
\end{abstract}

\section{Introduction}

According to the reports released in the last two years, there is a serious problem of employees' job-hopping with average turnover rate as high as 25 percent, in some companies, higher than 40 percent. This is caused by a relative low organizational commitment of employee. Therefore, how to deal with the relationship between the organization and employees and to enhance their organizational commitment has been the core of management and an urgent problem to solve.

Organizational commitment has positive meaning to both the employees and the organization. First, to organization, staff with high organizational commitment means lowed organization cost . Second, to employees, high organizational commitment to the organization and the job reflects their being in good condition and positive relationship with the organization, which is beneficial to their daily life.

Recently, researches on the correlation between employees' organizational commitment in IT industry and other relative variables emerge one after another, however, few of these researches discussed its influence factors in details. In order to cope with the relative low organizational commitment in IT industry and its negative effects, this paper aims to investigate the factors thus providing some countermeasures for IT industry.

\section{Research design}

\section{Organizational Commitment Scale}

On the basis of Meyer and Allen's three-factor model, Prof. Ling Wenquan put forward Chinese enterprise employees' organizational commitment five-factor model after practical study with large samples. These five factors are affective commitment, normative commitment, ideal commitment, economic commitment and choice commitment and they are defined as the following chart (Table 1.1).

This paper adopts interviewing method by taking IT industry's unique situation and other experts' relative finding into consideration. After communicating with some of the IT industry practitioners the author put forward a hypothesis model, which describes 28 factors influencing the five kinds of commitments including gender, marriage, length of service, trust to the leaders, satisfaction to the pay, support on work from the organization, work environment's satisfaction, support on life from 
the organization, satisfaction to the welfare, leader group's maintain ability, organization culture identify degree, organization dependability, interpersonal relationship, the society fair exchange degree, satisfaction to colleagues, team work spirit, organization identity in society, satisfaction to organization, level of education, position of employee, working levels, ability of leaders, satisfaction to promotion system, possibility of job-hopping, satisfaction to work, age of employee, location of organization, possibility of changing career.

Table 1.1 Definition of five-factors

\begin{tabular}{cl}
\hline Category & \multicolumn{1}{c}{ Definition } \\
\hline $\begin{array}{c}\text { Affective } \\
\text { Commitment }\end{array}$ & $\begin{array}{l}\text { Approve of affectionate to the organization; be willing to make } \\
\text { contributions to its survival and development even irrespective of pay; } \\
\text { won't quit under any temptation; }\end{array}$ \\
\hline $\begin{array}{c}\text { Normative } \\
\text { Commitment }\end{array}$ & $\begin{array}{l}\text { Take social regulation and professional ethics as the principle of the } \\
\text { attitude and behavior; be responsible for the organization; }\end{array}$ \\
\hline $\begin{array}{c}\text { Attach importance to personal growth and ideals; pay attention to } \\
\text { whether personal expertise is put into use in the organization or not and } \\
\text { whether the organization can provide chances for promotion to realize } \\
\text { the ambition; }\end{array}$ \\
\hline $\begin{array}{c}\text { Economic } \\
\text { Commitment }\end{array}$ & Stay to avoid economic loss; \\
\hline $\begin{array}{c}\text { Choice } \\
\text { Commitment }\end{array}$ & $\begin{array}{l}\text { Be Lack of chances for job-hopping; lacks necessary skills to find } \\
\text { another job; }\end{array}$ \\
\hline
\end{tabular}

\section{Sampling}

The sample comes from urban cities with developed IT industry like Dalian, Shenyang, Shenzhen, and Shanghai. The sampling is decided by such elements like sample size, possibility to collect data and representativeness of the data.

The 200 subjects in the sample include a wide range of employees in IT field from R\&D staff to administrative staff and support staff. The cluster random sampling methods are used in this study. Seven IT companies were selected: Neusoft in Dalian, Dalian Ember Technology Co Ltd, Chinasoft International in Shenyang, Huaxin Soft Technology Co Ltd, Haihui Information Technology Co Ltd, Huawei Technologies Co Ltd and Zhuyou Information Technology Co Ltd.200 questionnaires were issued and, for some reasons, only 191 were acquired and the return ratio was $95.5 \%$. The 191 questionnaires were sorted out by picking out some unfinished questionnaires and some with apparent problems. Finally, there were 180 effective questionnaires left with effective return ratio $94.24 \%$.

\section{Analysis of the influence factors to organizational commitment}

\section{Model construction of the influence factors to organizational commitment}

Research method. The method of this study is to process the data with SPSS software18.0 in the test of difference. Independent sample T-tests was carried out to examine the significant difference in means of the five different commitments. If $\mathrm{T}> \pm 1.96$, there is a significant difference. Otherwise, there is not.

Difference examination. (1) Influence of age to organizational commitment

Table 2.1 significance of difference in the Means of different ages

\begin{tabular}{ccccc}
\hline $\begin{array}{c}\text { Dimensions and } \\
\text { variables }\end{array}$ & Age & M & SD & t \\
\hline Affective & $<25$ & 2.8131 & .93205 & 1.104 \\
\cline { 2 - 4 } commitment & $26-35$ & 2.7932 & .90823 & \\
\cline { 2 - 5 } & $>36$ & 2.9577 & .84614 & \\
\hline
\end{tabular}




\begin{tabular}{|c|c|c|c|c|}
\hline \multirow{3}{*}{$\begin{array}{l}\text { Normative } \\
\text { commitment }\end{array}$} & $<25$ & 2.8976 & .78903 & \multirow[t]{3}{*}{$2.564 * *$} \\
\hline & $26-35$ & 2.7869 & .66787 & \\
\hline & $>36$ & 2.6789 & .67846 & \\
\hline \multirow{3}{*}{ Ideal commitment } & $<25$ & 2.8928 & .66754 & \multirow[t]{3}{*}{$2.378 * *$} \\
\hline & $26-35$ & 2.7863 & .57913 & \\
\hline & $>36$ & 2.6715 & .54938 & \\
\hline \multirow{3}{*}{$\begin{array}{l}\text { Economic } \\
\text { commitment }\end{array}$} & $<25$ & 3.3896 & .79106 & \multirow[t]{3}{*}{1.188} \\
\hline & $26-35$ & 3.5649 & .79765 & \\
\hline & $>36$ & 3.2423 & .79913 & \\
\hline \multirow{3}{*}{ Choice commitment } & $<25$ & 2.6753 & .76892 & \multirow[t]{3}{*}{1.234} \\
\hline & $26-35$ & 2.7456 & .87694 & \\
\hline & $>36$ & 2.5476 & .67456 & \\
\hline
\end{tabular}

It can be concluded from the data showed above that there is significant difference in the dimensions of normative and ideal commitment among employees in different ages. It can be obviously seen that employees under 25 have high ideal commitment. However, employees aged 26-35 have almost worked for over 10 years already. Life pressure has make them lack of passion and putting less time and energy in work. Most of the employees age over 36 have already realized their ambitions. They regard their work as a pleasure more than means of living.

(2) Influence of marital status to organizational commitment

Table 2.2 significance of difference in the Means of different marital status

\begin{tabular}{|c|c|c|c|c|}
\hline $\begin{array}{l}\text { Dimensions and } \\
\text { variables }\end{array}$ & Marital status & $\mathrm{M}$ & SD & $\mathrm{t}$ \\
\hline \multirow{2}{*}{$\begin{array}{c}\text { Affective } \\
\text { commitment }\end{array}$} & married & 2.4087 & 1.24757 & \multirow[t]{2}{*}{1.953} \\
\hline & unmarried & 2.2397 & .99760 & \\
\hline \multirow{2}{*}{$\begin{array}{c}\text { Normative } \\
\text { commitment }\end{array}$} & married & 2.3697 & 1.26543 & \multirow[t]{2}{*}{1.651} \\
\hline & unmarried & 2.6785 & .85465 & \\
\hline \multirow{2}{*}{ Ideal commitment } & married & 3.4619 & .90404 & \multirow[t]{2}{*}{$5.364 * *$} \\
\hline & unmarried & 3.3116 & .59780 & \\
\hline \multirow{2}{*}{$\begin{array}{c}\text { Economic } \\
\text { commitment }\end{array}$} & married & 3.9833 & .99965 & \multirow[t]{2}{*}{$5.758 * *$} \\
\hline & unmarried & 3.0413 & .83850 & \\
\hline \multirow{2}{*}{ Choice commitment } & married & 3.3767 & .76560 & \multirow[t]{2}{*}{1.475} \\
\hline & unmarried & 3.2978 & .57689 & \\
\hline
\end{tabular}

The data shows that there is significant difference between married and unmarried employees in both dimensions of ideal and economic commitment. First, in dimension of ideal commitment, married employees tend to be more responsible and always gain high social status and high income, which is good to the family. And in terms of economic commitment, unmarried employees have less economic pressure, however, certain level of material is required afer marriage. Therefore, married employees are under a lot of pressure so that they take economic commitment seriously.

(3) The influence of recognition to organizational culture

Table 2.3 the significance of difference in the means of the recognition to organizational culture

\begin{tabular}{|c|c|c|c|c|}
\hline $\begin{array}{l}\text { Dimensions and } \\
\text { variables }\end{array}$ & $\begin{array}{l}\text { Recognition to organizational } \\
\text { culture }\end{array}$ & $\bar{M}$ & SD & $\mathrm{t}$ \\
\hline \multirow{3}{*}{ Affective commitment } & Highly agree & 3.6574 & .98674 & \multirow[t]{3}{*}{$2.987 * *$} \\
\hline & Agree & 3.8756 & .67436 & \\
\hline & Disagree & 3.4675 & .76485 & \\
\hline \multirow{3}{*}{ Normative commitment } & Highly agree & 3.5748 & .78903 & \multirow[t]{3}{*}{$2.639 * *$} \\
\hline & Agree & 3.9764 & .66787 & \\
\hline & Disagree & 3.5467 & .56473 & \\
\hline \multirow{3}{*}{ Ideal commitment } & Highly agree & 2.7928 & .86754 & \multirow[t]{3}{*}{1.657} \\
\hline & Agree & 2.6637 & .77913 & \\
\hline & Disagree & 2.5715 & .74938 & \\
\hline
\end{tabular}




\begin{tabular}{ccccc}
\hline \multirow{3}{*}{ Economic commitment } & Highly agree & 2.3796 & .99106 & \multirow{2}{*}{1.365} \\
\cline { 2 - 4 } & Agree & 2.5849 & .69765 & \\
\cline { 2 - 4 } & Disagree & 2.2623 & .77913 & \\
\cline { 2 - 4 } Choice commitment & Highly agree & 2.4753 & .76892 & 1.287 \\
\cline { 2 - 4 } & Agree & 2.5456 & .87694 & \\
\cline { 2 - 4 } & Disagree & 2.3563 & .67456 & \\
\hline
\end{tabular}

Data from the above table shows that both affective commitment and normative commitment are significantly different from organizational cultural identity. If the employees are passionate and willing to devote themselves to the organization, it can be predicted that the working staff are culturally identical to the company. Because the values are accepted and have good influences on the employees during their working interactions, employees will have a stronger sense of identity to the organization.

(4) The influence of payment satisfaction on organizational commitment

Table 2.4 the significant difference in the means of the payment satisfaction to organizational commitment

\begin{tabular}{|c|c|c|c|c|}
\hline $\begin{array}{c}\text { Dimensions and } \\
\text { variables }\end{array}$ & $\begin{array}{c}\text { Payment } \\
\text { satisfaction }\end{array}$ & M & SD & $\mathrm{t}$ \\
\hline \multirow{2}{*}{$\begin{array}{l}\text { Affective } \\
\text { commitment }\end{array}$} & Highly agree & 2.1246 & .75642 & \multirow[t]{2}{*}{1.865} \\
\hline & $\begin{array}{c}\text { agree } \\
\text { disagree }\end{array}$ & $\begin{array}{l}1.9978 \\
2.2231\end{array}$ & $\begin{array}{l}.65476 \\
.75185\end{array}$ & \\
\hline \multirow{2}{*}{$\begin{array}{l}\text { Normative } \\
\text { commitment }\end{array}$} & Highly agree & 2.7654 & .63674 & \multirow[t]{2}{*}{1.784} \\
\hline & $\begin{array}{c}\text { agree } \\
\text { disagree }\end{array}$ & $\begin{array}{l}2.9764 \\
2.6757\end{array}$ & $\begin{array}{l}.46356 \\
.53672 \\
\end{array}$ & \\
\hline \multirow[b]{2}{*}{ Ideal commitment } & Highly agree & 1.9763 & .76954 & \multirow[t]{2}{*}{1.543} \\
\hline & $\begin{array}{c}\text { Agree } \\
\text { Disagree } \\
\end{array}$ & $\begin{array}{l}2.1365 \\
2.5647 \\
\end{array}$ & $\begin{array}{l}.67587 \\
.76534 \\
\end{array}$ & \\
\hline \multirow{2}{*}{$\begin{array}{l}\text { Economic } \\
\text { commitment }\end{array}$} & Highly agree & 2.4351 & .87235 & \multirow[t]{2}{*}{1.457} \\
\hline & $\begin{array}{c}\text { Agree } \\
\text { Disagree }\end{array}$ & $\frac{2.6534}{2.1765}$ & $\begin{array}{l}.72534 \\
.65487\end{array}$ & \\
\hline \multirow{2}{*}{ Choice commitment } & Highly agree & 3.6519 & .96254 & \multirow[t]{2}{*}{$3.354 * *$} \\
\hline & $\begin{array}{c}\text { Agree } \\
\text { Disagree }\end{array}$ & $\begin{array}{l}2.6598 \\
2.4537\end{array}$ & $\begin{array}{l}.65793 \\
.45783\end{array}$ & \\
\hline
\end{tabular}

Table 2.5 T value table of the basic assumption model Gamma matrix

\begin{tabular}{cccccc}
\hline Item & $\begin{array}{c}\text { Emotional } \\
\text { commitment }\end{array}$ & $\begin{array}{c}\text { Normative } \\
\text { commitment }\end{array}$ & $\begin{array}{c}\text { Ideal } \\
\text { commitment }\end{array}$ & $\begin{array}{c}\text { Economic } \\
\text { commitment }\end{array}$ & $\begin{array}{c}\text { Opportunity } \\
\text { commitment }\end{array}$ \\
\hline Gender & 0.253 & 0.451 & 2.084 & 0.358 & 0.475 \\
\hline Marital status & 1.953 & 1.651 & 5.364 & 5.758 & 1.475 \\
\hline Age of employees & 0.723 & 0.565 & 1.645 & 2.073 & 1.324 \\
\hline Trust in leadership & 2.476 & 1.578 & 1.971 & -2.061 & 3.462 \\
\hline Satisfactory inwork & 1.865 & 1.784 & 1.543 & 2.457 & 3.354 \\
\hline $\begin{array}{c}\text { Support for work of } \\
\text { the organization }\end{array}$ & 0.736 & 0.583 & 2.065 & 0.908 & 1.254 \\
\hline $\begin{array}{c}\text { Support for life of } \\
\text { the organization }\end{array}$ & 2.815 & 0.531 & 1.785 & 0.403 & -2.306 \\
\hline $\begin{array}{c}\text { Ability to maintain } \\
\text { leadership }\end{array}$ & 2.253 & 0.672 & 0.365 & 1.675 & 0.712 \\
\hline $\begin{array}{c}\text { Organization } \\
\text { dependability }\end{array}$ & 1.969 & 0.413 & 0.546 & 0.867 & -2.419 \\
\hline The level of social & -0.372 & 2.419 & 0.564 & 1.998 & 3.672 \\
\hline
\end{tabular}




\begin{tabular}{|c|c|c|c|c|c|}
\hline equity swap & & & & & \\
\hline $\begin{array}{c}\text { Satisfaction } \\
\text { towards colleagues }\end{array}$ & 1.876 & 2.764 & 1.245 & 0.675 & 0.543 \\
\hline $\begin{array}{l}\text { The spirit of } \\
\text { collective work }\end{array}$ & 1.911 & 2.567 & 0.419 & 1.374 & -1.113 \\
\hline $\begin{array}{c}\text { Satisfaction owards } \\
\text { organization }\end{array}$ & 0.969 & 0.518 & 1.413 & 1.131 & -2.107 \\
\hline Level of education & 0.476 & 1.275 & 1.992 & 0.116 & -1.989 \\
\hline $\begin{array}{l}\text { The position of } \\
\text { staff }\end{array}$ & 1.465 & 0.320 & 1.986 & 0.872 & 0.090 \\
\hline $\begin{array}{l}\text { The ability to work } \\
\text { of leader }\end{array}$ & 0.254 & 0.989 & 1.982 & 1.435 & 1.231 \\
\hline $\begin{array}{l}\text { Satisfaction of the } \\
\text { promotion system }\end{array}$ & 0.817 & 1.214 & 2.038 & 1.547 & 0.763 \\
\hline $\begin{array}{l}\text { Satisfaction of the } \\
\text { work }\end{array}$ & 0.563 & 1.091 & 2.363 & 1.652 & 0.861 \\
\hline The age of staff & 1.104 & 2.564 & 2.378 & 1.188 & 1.234 \\
\hline $\begin{array}{c}\text { Possibility of } \\
\text { diverted }\end{array}$ & 1.104 & 1.036 & 2.578 & 2.456 & 0.984 \\
\hline $\begin{array}{l}\text { Cultural identity of } \\
\text { the organization }\end{array}$ & 2.987 & 2.639 & 1.657 & 1.365 & 1.287 \\
\hline $\begin{array}{l}\text { Work environment } \\
\text { satisfaction }\end{array}$ & 2.457 & 1.230 & 2.201 & 1.472 & 0.975 \\
\hline relationships & 3.654 & 2.765 & 1.334 & 0.977 & 3.076 \\
\hline $\begin{array}{l}\text { Social recognition } \\
\text { of the organization }\end{array}$ & 3.471 & 0.675 & 2.937 & 0.869 & 0.767 \\
\hline $\begin{array}{c}\text { Organization } \\
\text { location }\end{array}$ & 0.453 & 1.876 & 1.443 & 1.115 & 0.813 \\
\hline $\begin{array}{c}\text { Satisfaction on } \\
\text { welfare }\end{array}$ & 2.897 & 0.987 & 0.214 & 2.875 & 0.974 \\
\hline $\begin{array}{l}\text { The possibility of } \\
\text { job-hopping }\end{array}$ & 0.312 & 1.675 & 2.364 & 2.587 & 0.391 \\
\hline The working level & 3.675 & 0.746 & 3.127 & 0.823 & 0.784 \\
\hline
\end{tabular}

According to the statistics, there is significant difference on payment satisfaction on dimension of choice commitment. The reason why some of the staff still stay in a group may be that they haven't found a better organization with higher payment. Once they are offered with high payment, there is great possibility that they are leaving the present organization.

The above four groups are the significant analysis, but as the space constraints, significant differences in the remaining 22 variables and organizational commitment will not be listed one by one. Table 2.5 is the results of various data.

The descriptive analysis results of the data from survey. For the collected data in this survey, the descriptive statistical analysis results are shown in Table 2.6. Mean stands for the mean scores on behalf of various organizational commitments, SD stands for its standard deviation, and the rest related to the coefficient matrix of the five different organizational commitments.

Table 2.6 correlation analysis of organizational commitment and each dimension

\begin{tabular}{|c|c|c|c|c|c|c|c|}
\hline $\begin{array}{c}\text { Variables } \\
\text { and } \\
\text { dimension }\end{array}$ & Mean & SD & $\begin{array}{l}\text { Organiza- } \\
\text { tional } \\
\text { commitm } \\
\text { ent }\end{array}$ & $\begin{array}{l}\text { Emotiona } \\
1 \\
\text { commitm } \\
\text { ent }\end{array}$ & $\begin{array}{ll}\text { Normative } & \text { Ideal } \\
\text { commit- } & \text { commit- } \\
\text { ment } & \text { ment }\end{array}$ & $\begin{array}{l}\text { Economic } \\
\text { commit- } \\
\text { ment }\end{array}$ & $\begin{array}{l}\text { Opportunity } \\
\text { commitment }\end{array}$ \\
\hline $\begin{array}{c}\text { Organiza- } \\
\text { tional } \\
\text { commitmen } \\
t\end{array}$ & 2.92 & 0.63 & 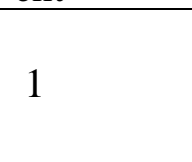 & & & & \\
\hline $\begin{array}{c}\text { Emotional } \\
\text { commitmen } \\
\mathrm{t}\end{array}$ & 2.75 & 0.90 & $\begin{array}{l}0.859 \\
* *\end{array}$ & 1 & & & \\
\hline
\end{tabular}




\begin{tabular}{cclllllll}
\hline $\begin{array}{c}\text { Normative } \\
\text { commitmen } \\
\mathrm{t}\end{array}$ & 3.34 & 0.79 & $\begin{array}{l}0.727 \\
* *\end{array}$ & $\begin{array}{l}0.622 \\
* *\end{array}$ & 1 & & \\
\hline $\begin{array}{c}\text { Ideal } \\
\text { commitmen } \\
\mathrm{t}\end{array}$ & 3.16 & 0.77 & $\begin{array}{l}0.744 \\
* *\end{array}$ & $\begin{array}{l}0.603 \\
* *\end{array}$ & $\begin{array}{l}0.550 \\
* *\end{array}$ & 1 & & \\
\hline $\begin{array}{c}\text { Economic } \\
\text { commitmen } \\
\mathrm{t}\end{array}$ & 3.26 & 0.68 & $\begin{array}{l}0.812 \\
* *\end{array}$ & $\begin{array}{l}0.641 \\
* *\end{array}$ & $\begin{array}{l}0.610 \\
* *\end{array}$ & $\begin{array}{l}0.761 \\
* *\end{array}$ & 1 & \\
$\begin{array}{c}\text { Opportunity } \\
\text { commitmen } \\
\mathrm{t}\end{array}$ & 3.18 & 0.81 & $\begin{array}{l}0.765 \\
* *\end{array}$ & $\begin{array}{l}0.609 \\
* *\end{array}$ & $\begin{array}{l}0.654 \\
* *\end{array}$ & $\begin{array}{l}0.654 \\
* *\end{array}$ & $\begin{array}{l}0.711 \\
* *\end{array}$ & 1 \\
\hline
\end{tabular}

The above statistical data results could meet the requirements of relative statistic, with reliability. Overall, it can explain the five different types of organizational commitment correlation to a large extent.

\section{The results of data analysis}

According to the above exploratory analysis, some factors that influence the five basic organizational commitments are concluded in the following table 2.8.

As is shown in the above data analysis, there are several key factors to influence them for every kind of organizational commitment. The management personnel of IT industry should analyze these key factors and know how they are applied to the organizational commitment. In addition, they should identify the key factors, which can help to make relevant systems and rules, making it favorable to improve workers' identification with the organizational commitment.

Table 2.7 The organizational commitment models that affect IT Industry

\begin{tabular}{|c|c|c|}
\hline Factors & Content & Influencing factors \\
\hline $\begin{array}{l}\text { Emotional } \\
\text { commitment }\end{array}$ & $\begin{array}{l}\text {-Identify the culture of the } \\
\text { organization, and have deep } \\
\text { feelings to the organization } \\
\text {-Attach great importance to the } \\
\text { development of the organization, } \\
\text { be willing to contribute to that end, } \\
\text { and sometimes even be willing to } \\
\text { sacrifice some personal interests } \\
\text {-Never leave the organization in } \\
\text { any case }\end{array}$ & $\begin{array}{l}\text {-Whether trust your leader or not } \\
\text {-The support from the organization } \\
\text {-The behaviors of the leadership team } \\
\text {-The reliability of the organization } \\
\text {-The identification with the organizational } \\
\text { culture } \\
\text { - Interpersonal relationship } \\
\text { - Social identification with the organization } \\
\text { - The work level }\end{array}$ \\
\hline $\begin{array}{l}\text { Norm } \\
\text { commitment }\end{array}$ & $\begin{array}{l}\text {-In daily work, constrain ourselves } \\
\text { strictly with social norms, } \\
\text { occupation morals and standards } \\
\text { - Take our obligation when } \\
\text { working, and be responsible for } \\
\text { our job. }\end{array}$ & $\begin{array}{l}\text { - The age of employees } \\
\text { - The identification with the organizational } \\
\text { culture. } \\
\text { - The level of social fair exchange } \\
\text { - The level of satisfaction with colleagues } \\
\text { - Teamwork sprit } \\
\text { - Interpersonal relationship }\end{array}$ \\
\hline $\begin{array}{l}\text { Ambition } \\
\text { commitment }\end{array}$ & $\begin{array}{l}\text {-Emphasize on personal } \\
\text { development and have their own } \\
\text { ambitions } \\
\text {-Whether personal professional } \\
\text { skills can be applied throughly in } \\
\text { the work } \\
\text {-Whether the organization can } \\
\text { offer employees opportunity of } \\
\text { studying and being trained to } \\
\text { improve the professional skills and } \\
\text { achieve our ambitions }\end{array}$ & $\begin{array}{l}\text {-Sex } \\
\text { - Marriage } \\
\text {-Trust in leaders } \\
\text { - The support from the organization } \\
\text { - Educational level } \\
\text { - Staff's position } \\
\text { - The ability of leaders } \\
\text { - The level of the satisfaction with work } \\
\text {-The system of promotion } \\
\text { - Workers' age } \\
\text {-The possibility of changing the job } \\
\text {-The work level }\end{array}$ \\
\hline
\end{tabular}




\begin{tabular}{|c|c|c|}
\hline $\begin{array}{l}\text { Economic } \\
\text { commitment }\end{array}$ & $\begin{array}{l}\text {-Leaving the current organization } \\
\text { will bring some economic loss. }\end{array}$ & $\begin{array}{l}\text {-Length of service } \\
\text { - Marriage } \\
\text {-The possibility of changing the job } \\
\text { - Welfare satisfaction } \\
\text { - The possibility of job-hopping } \\
\text {-The level of the satisfaction with the wage } \\
\text {-The level of social fair exchange } \\
\text {-The trust in leaders }\end{array}$ \\
\hline $\begin{array}{l}\text { Opportunity } \\
\text { commitment }\end{array}$ & $\begin{array}{l}\text {-Working in this organization just } \\
\text { because the workers haven't found } \\
\text { other appropriate organizations. } \\
\text { - The working ability is limited, } \\
\text { and not easy to find other jobs }\end{array}$ & $\begin{array}{l}\text {-The level of satisfaction with the wage } \\
\text {-The life support from organization } \\
\text {-The reliability on the organization } \\
\text {-The level of social fair exchange } \\
\text {-The level of the satisfaction with the } \\
\text { organization } \\
\text {-The educational level } \\
\text {-The interpersonal relationship }\end{array}$ \\
\hline
\end{tabular}

\section{Conclusion}

The countermeasures and the suggestions of improving the IT industry organizational commitment.

To improve employees' emotional commitment to the organization. (1)To improve staff's trust to leaders. if the leaders in the organization are able to lead the employees to achieve good performance with high prestige and working ability among the employees and have the leading role on the development of organization, employees will trust their leaders, and be willing to work under the guidance of the leaders, thus enhancing employees' emotion to the organization.

(2)To strengthen the support of organization for employees in life. Everyone's life is not plain sailing, and everyone's life is not only work. Therefore, employees will be affected by much chaos going on in their lives, which is inevitable. At this time, if the organization does not punish employees or show the cold shoulder but try to soothe and help employees, they will be very grateful to organization, and work harder in return for organization. In this process, employees' emotion to the organization will be greatly deepened.

(3)To promote the interpersonal relationship between the staff members in the organization. Interpersonal relationship is a very sensitive topic for some organizations. If the members in the organizations have bad relationships, the development of the organization may be affected seriously, and it also plays a negative role in the employees' relationship to the organization. A good interpersonal relationship will create a relaxed and pleasant working atmosphere, which makes the employees have a sense of belonging to an organization, and then the emotion to the organization will be multiplied.

To improve employee's normative commitment to the organization. (1) To enhance the recognition of staff to the organizational culture. As employees strengthen their overall perception of organizational culture, they can have a deeper understanding of relevant rules and regulations. In this sense, the normative commitment of employees is improved unconsciously.

(2) To improve the level of social fair exchange between the staff and the organization. we know, in fact, organization and employees are a kind of exchange in essence. However, the equality of this exchange is affected by the level of the employees' effort in their work. As employees, they hope that the material and spiritual rewards they acquire after working hard can be equal to their own efforts. But once the employees feel the relationship is unequal, the employees will produce sense of injustice psychologically. Then will not work hard as before: not being responsible in work, neglecting the rules and regulations of the organization to some extent. Therefore, the level of social fair exchange between the two is extremely significant to normative commitment.

To improve employees' ideal commitment to the organization. (1) To complete the system of the organization's promotion. The system of the organization's promotion is crucial to the development of the organization. Employees' ideal commitment can be enforced by the clarity and rationality of the system of the organization's promotion.

(2) To improve employees' job satisfaction. If employees are satisfied with their present work, they will derive great enjoyment from their work, entrust their ideals to their work and become 
more committed to the organization.

(3)To enhance employees' trust into the leadership of the organization. Leaders are the core people in an organization who influence and guide its development. If employees have no faith in their leaders, they will also lose their faith in the organization. Under such circumstances, employees' high level of commitment to the organization will be out of the question.

To improve employees' economic commitment to the organization. (1) Improve employees' satisfaction with salary and welfare. Since most relationships between organizations and employees are employment relationships, employees pay much attention to the salary and welfare offered by organizations. If salary and welfare are great, the organization will be appealing to employees and meanwhile the latter will be highly economically committed to the former.

(2) Some other factors can also influence employees' economic commitment, such as the level of fair exchange in society, seniority, marital status and probability of changing one's job. Therefore, human resource managers need pay attention to the formulation of relative policies.

To improve employees' choice commitment to organizations. (1) Improve employees' satisfaction with organizations. If employees are very satisfied with the organization, they will not ask for dismission. Hence, organizations should continuously improve themselves, carry out humanized patterns of management and become people oriented so as to improve employees' satisfaction.

(2) Improve employees' satisfaction with salary, enhance the reliability of organizations and increase the level of fair exchange between employees and organizations. These are also key factors for improvement of employees' economic commitment.

\section{Limitations and implications of the research}

Generally speaking, though the present research is, to some degree, of applicable significance, it has some limitations.

(1) The research is not scientific and accurate in terms of its analytical method. SPSS 18.0 is not the perfect software for data analysis whose defects will influence the result of the research.

(2)The key of the present research is to ascertain the respective key factors of five different kinds of organizational commitment. Organizational commitment, as a phycological feeling, is complicated and hard to measure. Moreover, it is subject to the cross influence of many factors. Therefore, the authenticity of data might be affected by the subjectivity of informants.

(3) Due to limitations of time and energy, samples used in the research are very limited.

\section{References}

[1] Meyer, J. P., Allen, N. J. (1997). Commitment in the workplace: Theory, research, and app lication. Thousand Oaks, CA: Sage.

[2] Mowday R T, Steers R M, Porter L W1. The Measurement of Organizational Commitment1 Journal of Vocational Behavior, 1979, 14: 22422471.

[3] Williams L J, Hazer J T1 Antecedents and Consequences of Satisfaction and Commitment in Turnover Models: Reanalysis UsingLa2tent Variable Structural Equation Methods1 Journal of Applied Psychology, 1986, 71: 21922311.

[4] Mathieu J E1 A Cross2level Nonrecursive Model of the Antecedents of Organizational Commitment and Satisfaction1 Journal of Ap2plied Psychology, 1991, 76: 49224991.

[5] Xiaoping Liu, Chongming Wang. The study of Organizations' commitment and formation process [J]. Nankai Business Review, 2001, 3(6): 58-62.

[6] Allen NJ, Meyer JP. Afective, continuance and normative commitment to the organization: an examination of construct validity[J]. Journal of Vocational Behavior, 1996, 49(6): 252-276.

[7] Porter LM, Steers RM, Mowday RT, et a1. Organizational commitment, job Satisfaction and tumover among psychiatric technicians[J]. Journal of Applied Psychology, 1974. 59(3): 603. 609. 